Inscribing the Environment 


\section{Fundamentals of Medieval and Early Modern Culture}

Edited by

Albrecht Classen and Marilyn Sandidge

13

De Gruyter 
Connie Scarborough

\title{
Inscribing the Environment
}

\author{
Ecocritical Approaches to \\ Medieval Spanish Literature
}

De Gruyter 
ISBN 978-3-11-030939-3

e-ISBN 978-3-11-026503-3

ISSN 1864-3396

\section{Library of Congress Cataloging-in-Publication Data}

A CIP catalog record for this book has been applied for at the Library of Congress.

\section{Bibliographic information published by the Deutsche Nationalbibliothek}

The Deutsche Nationalbibliothek lists this publication in the Deutsche Nationalbibliografie; detailed bibliographic data are available in the Internet at http://dnb.dnb.de.

(C) 2013 Walter de Gruyter GmbH, Berlin/Boston

Printing and binding: Hubert \& Co. GmbH \& Co. KG, Göttingen $\infty$ Printed on acid-free paper

Printed in Germany

www.degruyter.com 